\title{
Laparoscopic vaginal bead pull-through vaginoplasty technique using dental prosthesis material
}

\section{Diş protez malzemesi kullanilarak laparoskopik vajinal boncuk çekme vajinoplasti tekniği}

\author{
(1) Çetin Kılıççı, (1) İlhan Şanverdi, (1) Ezgi Darıcı, (1) Enis Özkaya \\ University of Health Sciences Turkey, Zeynep Kamil Women and Children's Diseases Training and Research Hospital, Clinic of Obstetrics and Gynecology, \\ İstanbul, Turkey
}

\begin{abstract}
Objective: Many reconstructive surgical procedures have been described for vaginal agenesis. Almost all are surgically challenging, multistage, timeconsuming or leave permanent scars on the abdomen or skin removal areas. The aim of this study was to introduce a simple and cheaper approach for laparoscopic vaginal bead-pull through.

Materials and Methods: In this retrospective study, we report a total of six patients with congenital absence of vagina [Mayer-Rokitansky-Küster-Hauser (MRKH) syndrome] who were treated with a laparoscopic vaginal bead pull-through technique between 2018 till 2019 with a dental prosthesis material. Results: Six patients with MRKH syndrome were treated with a laparoscopic vaginal bead pull-through technique. None of the women had any previous treatment. The mean age at the time of surgery was $18.7 \pm 3.1$ years and mean body mass index was 25 (range, 19-38) $\mathrm{kg} / \mathrm{m}^{2}$. None of the patients had any additional malformations. In all patients, normal external genitalia and complete vaginal agenesis were observed during examination. The mean duration of surgery was 72 (range, 55-95) minutes. All patients were discharged on the $3^{\text {rd }}$ postoperative day. No intraoperative complications were encountered. All patients had their urinary catheters removed within 12 hours after surgery. The mean vaginal length at discharge was 10 (range, 8-13) cm and all patients had adequate vaginal diameter, allowing introduction of three fingers easily. At the $12^{\text {th }}$ postoperative month, the mean vaginal length was $9.2 \pm 1.6 \mathrm{~cm}$. All patients had complete epithelization. All the women were sexually active one year after surgery.

Conclusion: The laparoscopic vaginal bead pull-through technique using dental prosthesis material can provide satisfactory results with shorter surgical time and lower cost.

Keywords: Absent vagina, Mayer-Rokitansky-Küster-Hauser, primary amenorrhea, vaginoplasty

Öz

Amaç: Vajinal ageneziye yönelik birçok rekonstrüktif cerrahi prosedür tanımlanmıştır. Hemen hemen hepsi cerrahi olarak zorlayıcı, çok aşamalı, zaman alıcıdır veya karın veya deri çıkarma bölgelerinde kalıcı izler bırakır. Bu çalışmanın amacı, basit ve daha ucuz bir yöntem olan laparoskopik vajinal boncuk çekme yaklaşımını sunmaktır.

Gereç ve Yöntemler: Bu retrospektif çalışmada, 2018-2019 yılları arasında diş protez malzemesi kullanılarak yapılan laparoskopik vajinal boncuk çekme tekniği ile tedavi edilen, doğuştan vajina yokluğu [Mayer-Rokitansky-Küster-Hauser (MRKH) sendromu] olan toplam altı hasta bildiriyoruz.

Bulgular: MRKH sendromlu altı hasta laparoskopik vajinal boncuk çekme tekniği ile tedavi edildi. Kadınların hiçbiri daha önce herhangi bir tedavi görmedi. Ortalama ameliyat yaşı 18,7 3,1 yıl ve ortalama vücut kitle indeksi 25 (aralık, 19-38) kg/m² idi. Hiçbir hastada ek malformasyon görülmedi. Tüm hastalarda muayene sırasında normal dış genital bölge ve tam vajinal agenez gözlendi. Ortalama ameliyat süresi 72 (dağılım, 55-95) dakika idi. Tüm hastalar postoperatif 3. günde taburcu edildi. İntraoperatif komplikasyonla karşılaşılmadı. Tüm hastaların idrar sondaları ameliyattan 12 saat sonra çıkarıldı. Taburculukta ortalama vajina uzunluğu $10(8-13 \mathrm{~cm}) \mathrm{cm}$ idi ve tüm hastaların yeterli vajinal çapı vardı ve üç parmağın kolayca girmesine izin verildi. Postoperatif 12 . ayda ortalama vajina uzunluğu 9,2 $1,6 \mathrm{~cm}$ idi. Tüm hastalarda tam epitelizasyon vardı. Tüm kadınlar ameliyattan bir yl sonra cinsel olarak aktifti.

Sonuç: Diş protez materyali kullanılarak yapılan laparoskopik vajinal boncuk çekme tekniği, daha kısa cerrahi süre ve daha düşük maliyet ile tatmin edici sonuçlar sağlayabilir.

Anahtar Kelimeler: Vajinal agenezi, Mayer-Rokitansky-Küster-Hauser, primer amenore, vajinoplasti
\end{abstract}

PRECIS: The laparoscopic vaginal bead pull through technique using dental prosthetic material can provide satisfactory results with shorter surgical time and lower cost.

Address for Correspondence/Yazışma Adresi: Assoc. Prof. Enis Özkaya,

University of Health Sciences Turkey, Zeynep Kamil Women and Children's Diseases Training and Research Hospital, Clinic of Obstetrics and Gynecology, İstanbul, Turkey

Phone: +90 5054742459 E-mail: enozkaya1979@gmail.com ORCID ID: orcid.org/0000-0001-6580-1237

Received/Geliș Tarihi: 27.02.2020 Accepted/Kabul Tarihi: 19.05.2020

${ }^{\oplus}$ Copyright 2020 by Turkish Society of Obstetrics and Gynecology

Turkish Journal of Obstetrics and Gynecology published by Galenos Publishing House. 


\section{Introduction}

Development of the mullerian canal is one of the most incomprehensible issues in gynecology. Each section of the mullerian canal has different reproductive functions. Complete absence of mullerian development leads to aplasia; the common form of partial development leads to tubal and partial uterine development, and complete absence of the upper threequarters of the vagina. In most cases of upper vaginal absence, the uterus is usually hypoplastic or primitive. The ovaries are normal, but are placed on the lateral pelvic wall along with the uterus. Classically, this is defined as Mayer-Rokitansky-KüsterHauser (MRKH) syndrome. The estimated prevalence is about 1:4000 to 5000 women $^{(1)}$. There are many surgical options to create a neo-vagina. Free skin graft ${ }^{(2)}$, intestinal or sigmoid vaginoplasty ${ }^{(3)}$, amniotic graft $^{(4)}$, and pelvic peritoneum $\operatorname{graft}^{(5)}$ have been used for these procedures. The disadvantages of previously defined procedures were stenosis, poor lubrication, scarring, contracture leading to dyspareunia, and the need for laparotomy. Transformation from free skin graft to squamous cell carcinoma and sigmoid to adenocarcinoma has been reported $^{(6)}$. Recently, there have been reports of neovagina formation with endoscopic help based on the Vecchietti technique $^{(7)}$. The use of peritoneum in vaginoplasty was first described in the Russian literature. This method was made popular by Davydov ${ }^{(8)}$. The formation of a neovagina using a laparoscope was first described by Semm ${ }^{(9)}$. More recently reported techniques describe laparoscopic application to replace the original Davydov procedure.

The aim of this report was to introduce a technique using a laparoscopic vaginal bead pull-through technique using dental prosthesis material.

\section{Materials and Methods}

After obtaining institutional ethics committee approval (University of Health Sciences Turkey, Zeynep Kamil Women and Children's Diseases Training and Research Hospital 2020/36), in this retrospective study, six patients with MRKH syndrome were treated with a laparoscopic vaginal bead pullthrough technique with dental prosthesis material from 2018 till 2019. The patients were followed from postoperative day 7 to a maximum of 12 months. The patients' ages ranged between 15 and 24 years. Apart from the routine preoperative study, a diagnostic laparoscopy was performed to see the size and position of the uterus in the lateral pelvic walls to determine the feasibility of creating a pelvic anatomy to create a route to pull through the bead and to determine the possibility of neovagina formation.

\section{Procedure}

A modified vaginal bead set was prepared from an acrylic material that has been used as a prosthesis in dentistry (Figure 1). A vaginal bead was created to draw the blind vagina, which is $2 \mathrm{~cm}$ long, $1 \mathrm{~cm}$ wide, $1 \mathrm{~cm}$ high, with two holes in it. In order to apply internal traction to the bead, two polydioxanone (PDS) sutures were passed through the holes and their proximal ends were connected to each other under the vaginal bead. Following the modified set preparation, the abdomen was entered with a $10-\mathrm{mm}$ trocar. Pneumoperitoneum was provided and suprapubic $5 \mathrm{~mm}$ trocars were placed on both sides. The bladder was removed cranioventrally from the anterior face of both round ligaments. The vaginal apex was sifted through the blind vagina using a thin Hegar cervical dilator, and the locations where the sutures were transported to the abdomen during laparoscopy were determined (Figure 2). The forceps of the $5 \mathrm{~mm}$ trocar were moved from under the peritoneum on both sides and the distal ends of the PDS sutures on the blind vaginal cuff were held with forceps and removed out of the abdomen under the peritoneum (Figure 3). Following abdominal washing, the procedure was terminated. The 10 $\mathrm{mm}$ trocar site was closed. The distal ends of both PDS sutures were pulled and traction was achieved with the vaginal bead in the blind vagina and the distal of the sutures were tied on a pad placed on the umbilicus. This pad on the umbilicus was used to stretch sutures to obtain the required vaginal length. The duration for hospital stay is 3 days in each case. After the traction technique is taught to the patient, she is

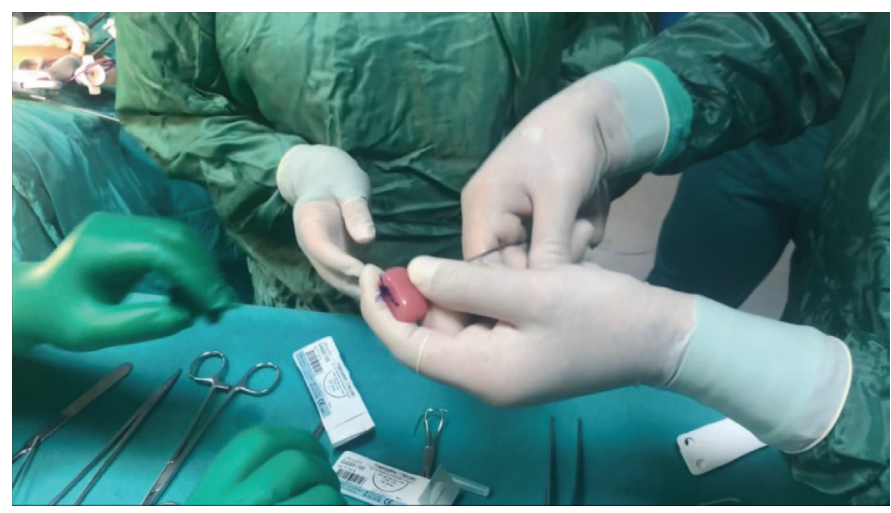

Figure 1. Cylindrical mass with two holes made of acrylic material used as a prosthesis in dentistry

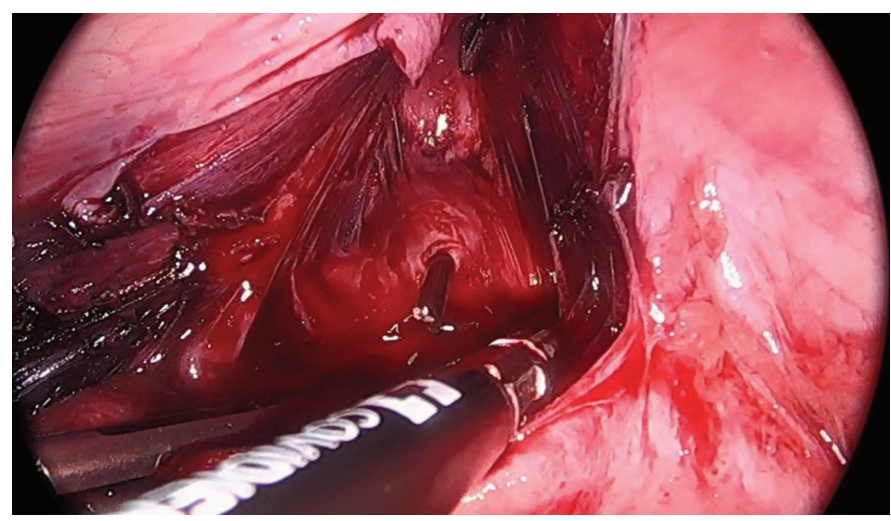

Figure 2. Pelvic peritoneal access using a Hegar cervical dilator through the neovagina 


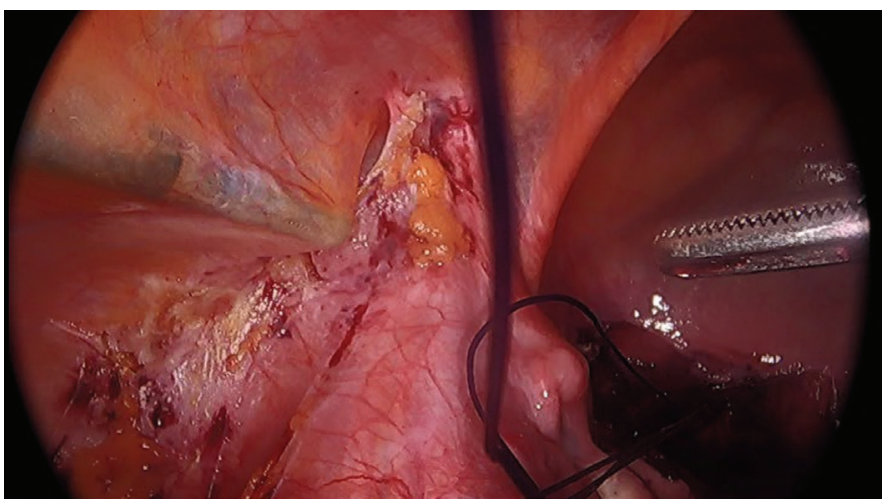

Figure 3. Extraperitoneally directed forceps to pull sutures from the neovagina to the lateral port sites

discharged. Patients perform traction on their own at home, using oral analgesics. The prosthesis is removed after a total of one week. Following removal of the prosthesis, dilatation was continued with a suitable mold accompanied by local estriol cream for 2 weeks. If the patient has a partner, coitus is recommended two days a week. A lubricant with ginseng or hyaluronic acid is recommended during intercourse. All participants were reevaluated at $12^{\text {th }}$ months postoperatively to determine the vaginal length and sexual activity.

\section{Statistical Analysis}

The statistical parameters were computed using the Statistical Package for the Social Sciences version 21.0 (SPSS Inc., Chicago, IL, USA). The continuous variables were expressed as the mean \pm standard deviation. The European categorical variables were expressed as the number and percentage.

\section{Results}

Six patients with congenital absence of vagina (MRKH syndrome) were treated using a laparoscopic vaginal bead pullthrough technique.

None of the women had any previous treatment. The mean age at the time of surgery was $18.7 \pm 3.1$ years and mean body mass index was 25 (range, 19-38) $\mathrm{kg} / \mathrm{m}^{2}$. None of the patients had any additional malformations. In all patients, normal external genitalia and complete vaginal agenesis were observed during examination. The mean duration of surgery was 72 (range, 55-95) minutes. All patients were discharged on the $3^{\text {rd }}$ postoperative day. No intraoperative complications were encountered. All patients had their urinary catheters removed within 12 hours after surgery. The mean vaginal length at discharge was 10 (range, 8-13) $\mathrm{cm}$ and all patients had adequate vaginal diameter, allowing the introduction of three fingers easily. At the $12^{\text {th }}$ postoperative month, the mean vaginal length was $9.2 \pm 1.6 \mathrm{~cm}$. All patients had complete epithelization. All women were sexually active one year after surgery.

\section{Discussion}

In this report, we tried to present our case series of six women with congenital vaginal agenesis who underwent vaginoplasty with a bead pull-through technique using a dental prosthesis; our data analysis showed satisfactory results with lower cost. MRKHS is caused by the hypoplastic embryologic development of the mullerian canal with the absence of the vagina, uterus or both ${ }^{(10)}$. Most patients have complete mullerian agenesis, and $47-84 \%$ of cases have uterine remnants with or without cavity $^{(11)}$. As a result of anatomic insufficiency, patients are compromised in terms of sexuality and reproductive health. The main basis of MRKHS management is to create a new anatomically sufficient and satisfactory vagina ${ }^{(12)}$ to provide comfortable intercourse with minimal intervention. To allow this function, the new vaginal canal must meet the following conditions; secretory function for sufficient width, length, axis, and also lubrication. None of the many techniques ${ }^{(13)}$ proposed to date meet all these criteria. Following some conventional approaches for neovagina surgical techniques, newer modified forms of more satisfactory minimal invasive techniques have been introduced ${ }^{(14)}$; however, each procedure has been suggested to have specific disadvantages and complications based on the characteristics of the procedure and materials or tissues used to create a neovagina. A previously published review addressed all these specifically observed complications related to intestine, skin, buccal mucosa, and peritoneum ${ }^{(15)}$. Disadvantages specific for the procedures using peritoneum were defined as these procedures typically reserved for patients who have not had prior pelvic surgery and therefore its applications are limited. The risks of this procedure include injury to the bowel and bladder, as well as prolapse. Up to $23 \%$ of patients with a Davydov procedure will experience granulation tissue and $12 \%$ will have obliteration of the vaginal canal; furthermore, postoperative dilation is essential ${ }^{(16)}$. Self-lubricating neovagina has been provided by vaginal reconstruction using isolated bowel segments with low rates of failure and revision, additionally routine dilatation is not required for this procedure. It was reported that vaginoplasty using bowel was a safe and effective procedure ${ }^{(17)}$. Vecchietti and Davydov's methods have been introduced as two commonly preferred laparoscopic options. The Vecchietti operation relies on passive upwards traction with an externally replaced spherical device rather than dilatation $^{(18)}$, pain due to continuous traction and the need for prolonged hospitalization for continuous strong analgesia have been reported as the main disadvantages ${ }^{(19)}$. Finally, the device used for the technique has not yet been approved by the Unites States Food and Drug Administration, and it significantly increases the cost of the operation ${ }^{(14)}$. For this reason, some other alternative materials have been proposed to be used for this purpose ${ }^{(20)}$. In our proposal, we used a cheaper material that has been used as a prosthesis in dentistry, which indicates its safety for this procedure. The laparoscopic Davydov procedure is based on pulling down parietal peritoneum 
and suturing it to the vaginal introitus. A comparison of the procedures reveals that both Vecchietti and Davydov's laparoscopic techniques are simple, safe, and effective surgical methods for vaginal reconstruction; Vecchietti's procedure is more time-efficient and minimally invasive, on the other hand, Davydov's procedure is associated with less pain, a longer vagina, and greater sexual satisfaction ${ }^{(11)}$. Evidence shows that laparoscopy-assisted peritoneal vaginoplasty by pushing down the peritoneum offers the advantages of reduced costs, complications, hospitalization, surgical time, and pain over the traditional technique ${ }^{(21)}$; however, further modifications may provide additional advantages for these approaches.

\section{Conclusion}

The laparoscopic bead pull-through technique using dental prosthesis material can provide satisfactory results with shorter surgical time and lower cost. As the dental prosthesis has been shown to be safe to use on oral mucosa, this property of material may prevent unexpected tissue reactions.

\section{Ethics}

Ethics Committee Approval: Ethics committee approval (University of Health Sciences Turkey, Zeynep Kamil Women and Children's Diseases Training and Research Hospital 2020/36).

Informed Consent: Retrospective study.

Peer-review: Externally peer-reviewed.

\section{Author Contributions}

Concept: Ç.K., Design: Ç.K., Data Collection or Processing: E.Ö., E.D., İ.Ş., Analysis or Interpretation: E.Ö., Literature Search: E.Ö., Writing: E.Ö., E.D.

Conflict of Interest: The authors declare no conflicts of interest.

Financial Disclosure: The authors declared that this study received no financial support.

\section{References}

1. Capero V, Gallego M. Vaginal agenesis. Am J Obstet Gynecol 1976;124:98-107.

2. Wesley JR, Coran AG. Intestinal vaginoplasty for congenital absence of vagina. J Pediatr Surg 1992;27:885-9.

3. Wiser WL, Bates GW. Management of agenesis of vagina. Surg Gynecol Obstet 1984;159:108-12.

4. Ashworth MF, Morton KE, Dewhurst J, Lilford RJ, Bates RG. Vaginoplasty using amnion. Obstel Gynecol 1986;67:443-6.

5. Soong YK, Chang PH, Lai YM, Lee CL, Chou HH. Results of modified laparoscopically assisted neovaginoplasty in 18 patients with congenital absence of vagina. Human Reprod 1996;11:200-3.
6. Hopkins MP, Morley GW. Squamous cell carcinoma of the neovagina. Obstet Gynecol 1987;69:525-7.

7. Vecchietti $G$. Construction of a functional vagina: A new approach to the RKH syndrome. Clin Exp Obstet Gynecol 1974;2:3-8.

8. Davydov SN. Obstel Gynecol (Moscow) 1969;12:55.

9. Semm K. Pelviscopiche Kontrolle der neovaginaen operationstechnik ubcer eine gliederoptik. Alete wissenschaftlicher dienst 1983;93:247.

10. Edmonds DK. Congenital malformations of the genital tract and their management. Best Pract Res Clin Obstet Gynecol 2003;17:1940.

11. Dong X, Xie Z, Jin H. Comparison study between Vecchietti's and Davydov's laparoscopic vaginoplasty in Mayer-Rokitansky-KusterHauser syndrome. Zhonghua Fu Chan Ke Za Zhi 2015;50:278-82.

12. Fedele L, Frontino G, Restelli E, Ciappina N, Motta F, Bianchi S. Creation of a neovagina by Davydov's laparoscopic modified technique in patients with Rokitansky syndrome. Am J Obstet Gynecol 2010;202:33.

13. Ismail-Pratt IS, Bikoo M, Liao LM, Conway GS, Creighton SM. Normalization of the vagina by dilator treatment alone in complete androgen insensitivity syndrome and Mayer-Rokitansky- Ku sterHauser syndrome. Hum Reprod 2007;22:2020-4.

14. Uncu G, Özerkan K, Ata B, Kasapoğlu Işıl, Atalay MA, Adnan O, et al. Anatomic and Functional Outcomes of Paramesonephric Remnant-Supported Laparoscopic Double-Layer Peritoneal PullDown Vaginoplasty Technique in Patients With Mayer-RokitanskyKüster-Hauser Syndrome: Uncu Modification. J Minim Invasive Gynecol 2018;25:498-506.

15. Oelschlager AMA, Kirby A, Breech L. Evaluation and management of vaginoplasty complications. Curr Opin Obstet Gynecol 2017;29:316-21.

16. Willemsen W, Kluivers K. Long-term results of vaginal construction with the use of Frank dilation and a peritoneal graft (Davydov procedure) in patients with Mayer-Rokitansky-Kuster syndrome. Fertil Steril 2015;103:220-7.

17. Georgas K, Belgrano V, Andreasson M, Elander A, Selvaggi G. Bowel Vaginoplasty: A Systematic Review. J Plast Surg Hand Surg 2018;52:265-73.

18. Fedele L, Bianchi S, Frontino G, Fontana E, Restelli E, Bruni V. The laparoscopic Vecchietti's modified technique in Rokitansky syndrome: anatomic, functional, and sexual long-term results. Am J Obstet Gynecol 2008;198:377e1-e6.

19. Deans R, Berra M, Creighton SM. Management of vaginal hypoplasia in disorders of sexual development: surgical and 401 non-surgical options. Sex Dev 2010;4:292-9.

20. Mishra B, Janavar G, Pradeep Y, Singh AK, Kumar V, Upadhyay $\mathrm{DN}$. Indigenous technique of fabricating vaginal mould for vaginal reconstruction and uterine drainage in McIndoe vaginoplasty using $10 \mathrm{ml}$ syringe. Indian J Plast Surg 2016;49:76-80.

21. Wu J, Guo R, Chu D, Wang X, Li L, Bian A, et al. Comparison of Two Techniques of Laparoscopy-Assisted Peritoneal Vaginoplasty. J Minim Invasive Gynecol 2016;23:346-51. 